Alexandra Lipasova

\title{
FATHERHOOD IN THE RUSSIAN PROVINCES: A THEORETICAL AND EMPIRICAL ANALYSIS
}

The article explores gender contracts and fatherhood models that are present in families living in small Russian towns. Firstly, the key characteristics of the social groups in this research, 'potential middle class' and 'manual workers' are defined. This is followed by a review of two parental educational strategies: concerted cultivation and accomplishment of natural growth. Two theoretical explanations for gender imbalance in the division of unpaid family labour are offered. These are the economic/bargaining perspective and the gender perspective. Then, drawing on in-depth interviews with fathers and mothers from small Russian towns, the conclusion is reached that fathering practices in these families have situational character, defined by, in Bourdieu's term, their 'habitus'. Many fathers still keep a 'low bar for fatherhood'. The less affluent families from Russian provinces do not rate their children's opportunities for social mobility very highly, so they motivate them to be successful in sports, thus accomplishing a variant of the 'natural growth' educational strategy. The gender contract in these families can be characterized by distinct gender imbalance; many fathers still think that house work and childcare are a mother's responsibility. Even the fathers who were labelled as 'involved' demonstrate rigid views on the preferred life trajectory of their daughters. It is noted that the degree of father's involvement depends on the partners' negotiating the terms of their family gender contract. Traditional gender ideology and notions about gender inequality make parenthood the sole responsibility of mothers, and breadwinning the ultimate duty of fathers.

Key words: fatherhood, parenthood, gender contract, educational strategies, involved fatherhood

DOI: $10.17323 / 727-0634-2017-15-4-629-642$

Alexandra Lipasova - PhD student, Department of Sociology, National Research University Higher School of Economics, Moscow, Russia. Email: alexandra.lipasova@gmail.com 
Families are responsible for the socialization of individuals from the birth to adolescence in many major aspects from physical to ethical and educational. In Pierre Bourdieu's theory of capitals, he introduces the concept of 'habitus': a set of dispositions, or schemas of thinking, perception and evaluation, embedded in a body, which are formed in childhood and adolescence and then taken for granted (Bourdieu 2001). Bourdieu suggests that differences in habitus give individuals varying cultural skills, social connections, educational practices, and other cultural resources, which can be translated into different forms of assets (which he calls 'capital') as individuals move out into the world. It is possible to adopt new habits later in life, but these late-acquired dispositions lack the comfortable (natural) feel associated with those learned in childhood. This article concerns with performance of families in the described processes. To be exact, it focuses on one aspect, fathering practices in two social groups: 'potential middle class' and 'manual workers'. According to the latest research, these groups' share of the Russian population as whole is $58 \%$, $19 \%$ and $39 \%$, respectively (Anikin, Tikhonova 2016).

One of the main features of the transition from the industrial to the postindustrial society in developed countries is the approximate equality in the incomes of skilled workers and the middle class (Karavay 2016). Simultaneously there is an increase in the number of non-manual workers, employed in the trade and service sectors, known as the 'potential middle class' in Russian surveys. Despite its name, this group is characterized by low level of education, which allows researchers to conclude that its representatives will not become members of the middle class either now or in the future due to this lack of credentials (Anikin, Tikhonova 2016). Robert Erikson and John Goldthorpe's research showed that, during the second half of the twentieth century, highly qualified manual workers, as well as non-managerial employees in the trade and service sectors, were very different from professional 'white collars' in terms of their values and behaviour patterns, which were closer to lower qualified manual workers (Erikson, Goldthorpe 1992). The authors came to the conclusion that manual workers and non-managerial employees in the trade and service sectors are characterized by specific behaviours and lifestyles, which are different from those in other social classes. Particularly, they are prone to demonstrative consumption and have a short planning horizon (see also, Karavay 2016).

Fathering practices in various social classes has been studied before. Using Bourdieu's concepts, Anette Lareau analysesd parenting practices in American families belonging to middle and working classes. She introduced the notions of concerted cultivation and accomplishment of natural growth (Lareau 2011). The first term refers to parenting practices typical of the middle class, such as active participation in children's lives, talking with children about their teachers, class mates and friends, eagerness to listen to children, and engaging them in different kinds of activities like sport, music, other creative hobbies. This follows a very dense schedule of activities, and is led by the 
desire to evaluate and encourage children's proneness to certain activities, skills and wishes. The second, the accomplishment of natural growth, is a strategy used by less well-off social groups. It is characterized by a lack of organized children's schedules and by mainly outdoor entertainment with their siblings and children from the neighbourhood. Many of the 'blue collar' parents noticed their children's interest in sports or art, but were not eager to develop these skills. The main goal of the parents from this social group is to take care of their children's health, provide for their 'physical existence', leaving the children in charge of their own development.

Lareau concluded that well-off parents acted as intermediaries between their children and teachers or coaches. Less affluent parents were afraid of dealing with authorities and preferred not to interfere. In their opinion, the education was the job of teachers not parents. Lareau argues that neither of the parenting styles could be considered the best. The children from less affluent families more frequently demonstrate respect for adults than their counterparts from the middle class, they are less fussy, more independent and report that they are 'bored' much less often. However, in practical terms, the strategy of concerted cultivation gives a lot of advantages. The children from well-off families, who are loaded with various activities, constantly gain new experiences. Contrary to them, the children from poorer families do not know how to get what they want and adjust a given situation to their needs.

By incorporating the theory of capitals into her research of 'unequal childhoods', Lareau states that Bourdieu would never suggest that more parents could improve their children's school success by adopting particular middle-class practices. The number of different class slots in society is limited. Thus, any effort to spread a prestigious practice to all members of the society would result in the practice being devalued and replaced by a different sorting mechanism. In this sense, Bourdieu's model suggests that inequality is a perpetual characteristic of social groups. In any given social interaction, however, Bourdieu stresses that the outcome is unpredictable. It depends on the quality of 'the game', i.e. the initial positions of the individuals, which are set by the rules of 'the game', and the more or less effective skills to use them (Bourdieu 2001:288).

Keeping this theory in mind, I aim to investigate what gender contracts, fatherhood models and parenting strategies are characteristic of the families living in small Russian towns. In this research, gender contracts are understood as sets of principles according to which the family decides who and by what resources conducts the housework and family chores inside and outside the family. I focus my research on fathering practices to explain how the existent division of domestic labour impacts the level of fathers' involvement in childcare. In the first part of the article I describe my data and method, then I elaborate on the concept of gender contract and give theoretical and historical explanations of its developments in Russia. In the second part of the article I turn to fatherhood models in Russian province and conclude that the level of fatherhood involvement depends on the 
father's perception of his role in the family and the effectiveness of partners' negotiating regarding their respective obligations and expectations from each other.

\section{Data and Method}

This study is a part of a wider research of fatherhood models in different social groups in Russia, and my attention was specifically drawn to the families that belong either to potential middle class, or to manual workers. The main criteria for choosing the respondents were their type of employment (trade or service workers, manual workers) and education (high school or professional college, no university degree). The respondents were from twenty-eight to forty years old and identified as ethnically Russian. The empirical base of the research consist of twenty-one in-depth interviews with fathers (eleven interviews) and mothers (eight interviews) from different families (meaning they are not partners) and two couples (one interview was taken with both partners and the other one was taken separately with each partner). The interviews were taken in two small Russian towns: Gorokhovets (Vladimir region, population of 13,000) and Totma (Vologda region, population of 10,000). ${ }^{1}$

The respondents were asked questions about the history of their family, its structure, gender contract and everyday responsibilities of the mother and father, and about norms and values concerning fatherhood in general. As Jennifer Mason (2002) concludes, most qualitative research operates from the perspective that knowledge is situated and contextual. For some that extends into the assumption that data and knowledge are constructed through dialogic (and other) interactions during the interview. Meanings and understandings are created through interaction, which is affectively a co-production, involving researcher and interviewees. In my particular case topic-centred biographical interviews allowed me to construct knowledge in a relatively informal style.

Still the research certainly has limitations. First of all, not many men were eager to speak about their family life with a woman-interviewer; on several occasions the attempts to ask questions were met with hostility. The female respondents sometimes used the interview to complain about their husbands and men in general. But overall, I think that the conducted research offers a distinct picture of fatherhood in small Russian towns.

\section{Family Gender Contracts}

In the social groups of potential middle class and manual workers' families, gender contracts are characterized by strong inequality in the division of household labour between partners. There are two explanations to this phenomenon in

\footnotetext{
${ }^{1}$ The interviews in Totma were taken by the author, the respondents from Gorokhovets were interviewed by Tatiana Larkina (NRU HSE).
} 
the literature: the economic/bargaining perspective and the gender perspective (Sayer 2005). The former perspective emphasizes rationality and relative resource levels as the reason why women's and men's time allocations should have changed in response to shifting economic, demographic and normative conditions. Women's rising educational attainment and wages have reduced their comparative advantage in unpaid (relative to paid) work, at the same time that declining marriage rates, the increasing age at first marriage and falling fertility have reduced unpaid work demands. Furthermore, because increases in women's education, employment and earnings have improved their bargaining power, men's unpaid work should also be increasing (Blau 1998).

The gender perspective instead emphasizes the resilience of gender inequality and elements that work against change in the gender division of labour. According to this perspective, unpaid work is not a gender-neutral bundle of chores that people perform out of comparative advantage or lower resources but is instead integral to the reproduction of unequal power relations between women and men. In not doing unpaid work, or at least avoiding certain activities, men display their masculinity and reinforce their structural and cultural power (Risman 2004). Thus, while definitions of acceptable feminine behaviour have been broadened to include wage earning, the women's performance of domestic labour is still part and parcel of being a 'good' wife and mother. The devaluation of domestic labour is built into appropriate norms of femininity and masculinity, meaning it is more acceptable for women to adopt 'masculine' behaviours, such as doing paid work, than for men to adopt 'feminine' behaviours, such as doing unpaid work. According to gender perspective, women should continue performing 'acceptable' amounts of domestic labour while men should not have increased unpaid work time to any substantial degree. Women should also have less free time than men because they are responsible for ensuring that all unpaid work gets done, regardless of how much time they spend on paid work (Sayer 2005).

Both the economic and gender perspectives find support in the empirical literature (Bianchi et.al. 2000; Coltrane 2000). While women have increased their hours of paid employment, men still spend more hours in paid work than women, and married men allocate more time to paid work compared to married women (Sayer et.al. 2004). Findings from cross-sectional data imply that women still do more housework and childcare than men, and marriage, children and employment increase women's household labour but have little or no effect on men's unpaid work. The reallocation of women's and men's time is still not fair, because male identity is entangled with being the breadwinner, while female identity is enmeshed with being a caregiver (Hochschild, Machung 2012).

However, according to Francine Deutsch (2010), justifying the lack of men's involvement in domestic work on the ground of male privilege seems to have become taboo. She specifies five indirect resistance strategies that men use: (1) passive resistance (ignoring the request for help); (2) incompetence, which allows men to justify the gender-based distribution of domestic labour; (3) praise 
(although it can be a sincere expression of appreciation, it may also have an insidious effect of keeping the work in the women's domain); (4) different standards (men's spoken or unspoken claim is that they do not care as much as their wives about the clean house, nutritious dinner or after school activities of their children); (5) denial (men exaggerate their own contributions by comparing themselves to different generations and attribute greater contributions of their wives to their wives' personalities and preferences).

\section{Gender Contracts in Russia}

Evidence of both economic and gender perspectives were found in interviews conducted in small Russian towns. Due to the lack of employment opportunities for women with children, their bargaining power is quite low. As for gender ideology, it structures the usage of resistance mechanisms that fit within a certain gender ideology, i.e. the way a person identifies herself or himself in terms of their marital and family roles is linked to gender. And gender ideology is a part of a person's habitus. I will return to this point in more detail in my empirical analysis.

Jennifer Utrata $(2008,2015)$ argues that Russian fathers reproduce dominant gender discourses, where men are seen as irresponsible and infantile, and fatherhood is not of much value to them. Utrata suggests that the minimalistic requirements of fatherhood (she calls it 'keeping the bar low') allow Russian men to stay good fathers in their own eyes. In their view, the mother has the priority significance in a child's life while the father's presence is not obligatory. Even the fathers who are open to a new more involved version of fatherhood accept a negative perception of men as bad parents. It helps them to avoid parental responsibility and not to 'lose face'. Though old narrow standards of fatherhood related to being the main breadwinner are less popular in Russia now, they remain attractive for Russian men. The current cultural and socio-economic context pushes them to 'detached fatherhood' - the opposite of the involved one.

Gender ideology has been changing in Russia throughout the twentieth and twenty-first centuries. Most of the respondents in our research are second- and third-generation descendants of Russian peasants, so their grandparents were likely to live according to traditional gender contract of the Russian rural areas: women with children (molodukha) were in charge of the household and childcare and reported to their mothers-in-law (bolshukha), while married men ( $m u$ zhik) were responsible for themselves and their wives in front of their fathers and society (Adonyeva, Olson 2016). Later men could head their peasant communities (bolshak). Svetlana Adonyeva and Laura Olson conducted fieldwork in the North-West of Russia, so their observations are especially true for the ancestors of the respondents living in the town of Totma (Vologda region). The authors argue that in the Soviet period the socialization of men stopped at the stage of responsibility attained by the muzhik. The Soviet generations acquired behavioural practices typical for unmarried men (paren'), namely, orientation 
towards the values of the peer group at the expense of family interests, responsibility towards peers, risk and aggression. Men's behaviour was evaluated not by the older men in the community, but by the Soviet authorities, where the relationships between men took a form of 'men's union', where collective values stood above those of the family and the individual (Adonyeva, Olson 2016: 85).

Today's official family discourse revolves around 'traditional family values'. As Anna Shadrina argues, promotion of such values means that the state transfers responsibility for families' well-being to families themselves (2017: 173). In societies with a traditional gender division of labour, childcare automatically becomes the women's obligation. In Soviet times the state partly shared it with mothers, thus giving them the possibility to combine employment and housework; parental leave was long and paid, the number of kindergartens was sufficient, families were offered after-school care and summer camps for children. In contemporary Russia 'traditional family values' are based on intensive motherhood, i.e. making the mother the main responsible person for the child's wellbeing and prioritizing the child's needs over those of the mother (Hays 1996).

Fathers also have the right to take the parental leave. But from a financial point of view, taking leave is beneficial only for a partner who earns less (and usually it is the mother), since the maximum amount of payment is $40 \%$ of the monthly salary but no more than 23,120 roubles in 2017 (Federal Law 1995, 2015). In gender-segregated societies based on 'traditional family values', men see the family as an exemption from care obligations, so their professional success is partly provided by the invisible family labour of women (Shadrina 2017:242).

\section{Gender Contracts in the Interviews}

What can be found in the narratives of the respondents from small Russian towns is a distinct 'gender misbalance', i.e. the gap between the real gender contract in the family and the way it is articulated by the respondent. For example, when asked: 'What is it to be a good father in your opinion?', the respondents most frequently answered: 'To be the defender and the provider of the family'. However, in their autobiographic narratives and the narratives of their partners, men may not have followed this normative pattern:

I have never had a permanent job. It requires courage to be ready for changes and look for a new job...I respect the men who do not walk around saying: I am such a good father of the family (male, Totma, 33 years old, father of three, a shift manual worker).

In this quotation, the head of the family admits that having a permanent source of income is not his priority, and he does not consider it mandatory. Meanwhile, his wife regards their family arrangement as unfair: 'I provided for the whole family, and my mother, and the children... I may be digging out potatoes, and he has gone fishing' (female, Totma, 31, mother of three, nurse). The deeply embedded notions that men are strong defenders and providers and 
women are weak and should take care after children actually can transform into a gender contract, in which the men are normally infantile and irresponsible, and the women have to do 'the double shift'.

According to Elizabeth Bott (1955), there is another mechanism which explains the gender contract in certain communities. Families in which the rolerelationship of the husband and wife is segregated have dense social networks in which many of their relatives, friends and neighbours know each other. Families with a joint role-relationship between husband and wife have dispersed social networks. Bott concludes that the density of the social network directly influences the division of roles in family gender contract. This is true for the realities of the two Russian small towns: the social network is very dense and tight; the responsibility for childcare lies on women. Looking after children is done not by a family member, but by someone from a neighbourhood, i.e. women take turns in looking after the children from their yard (dvor), while other mothers are at work or conduct other types of household chores:

They [her neighbours] turn to me, I don't ask them... If they need to go to work or if they need to go to a store. I don't usually refuse them and baby-sit... And I cope myself (female, Gorokhovets, 32, mother of three, manual worker's wife).

The strategy of 'coping oneself' can be found in many mothers' narratives. Sometimes these women took particular pride in their ability to take care of everything while emphasizing the helplessness of their husbands:
As a rule, men here are at work or in front of the TV, at home... My husband was brought up in a family, where the father only did the work outdoors - they prepared firewood, cleared away snow. He can't even bathe a child... Now very few men help to care after children (female, Gorokhovets, 30, mother of three, manual worker's wife).

Surprisingly, what was absent in the women's narratives was any effort to talk over the current gender contract and the state of family affairs which many female respondents find unfair. This 'coping oneself' strategy is a part of these women's habitus and they consider it as something pre-defined. Male respondents did not evaluate their inter-family arrangement in terms of its fairness or inequality. They also showed no regret or remorse for not helping their wives more. In the next section, I shall shift the focus to how fatherhood was manifested in our interviews.

\section{Fatherhood Models in a Small Russian Town}

Fathering practices, which are typical of potential middle class and manual workers, are situational in character and are defined by habitus. The conducted interviews with families allow us to distinguish a set of fatherhood models. Firstly, there is the 'absent/infantilized' father. The fathers in this 
group do provide for their families to certain extent (many mothers argued that their husbands give them only a fixed part of their salaries and it is not enough), but mainly they can be characterized by passivity; it is often that they get support from the mothers and that they are only involved in most pleasant and the least time-consuming fathering practices, like playing with children. It is manifested in such responses, when asked about husband's participation in the family: 'Basically, only this one: he has eaten, slept, played and gone to work' (female, Gorokhovets, 32, mother of three, manual worker's wife).

Fatherhood motivations and the very value of having children are of vague significance for absent fathers, they do not take enough responsibility for their children, their role in the family is passive. Utrata defines such a position as precarious and marginalized (Utrata 2015). But mothers themselves often perceive the lack of their husbands' wish to take part in childcare and become emotionally involved in parenthood as normal and unconsciously support this state of affairs (Ashwin, Lytkina 2004). These families are bound by traditional gender ideology gone through the Soviet transformation, in which fatherhood is optional and motherhood is essential:

Interviewer: Do fathers help?

Respondent: Oh, no. They drink and cheat. Here the majority of families are together because of the children... I ask my girlfriends: Why do you have this in your families? They say: we are family, the child needs a father. I say: The child is better without any father, than with the one like that (female, Totma, 28, mother of one, manual worker's wife).

'Staying together for the sake of the children' with little support from the father is a common topic in the interviews with women respondents. Growing up in a two parents family is considered an important part of children's wellbeing. Moreover, the status of a divorced mother bears a stigmatised character in small Russian towns. On some occasions, women could not name the reasons why they stay together with the partners who are of no support to them:

This person [her husband] lives according to the principal: other people have wives, and I also need one, other people have children, and I also need them... There is no love in our family (female, Gorokhovets, 30, mother of three, manual worker's wife).

In families with an absent father cases of physical and emotional abuse are common. Researchers have linked cases of domestic violence by fathers to conditions of destitution generating stress and anomy in the family. This is also linked to the fathers' personality traits, such as an aggressive or addictive personality; or to a patriarchal system of power (Rodríguez-Ménes et.al. 2014). This is confirmed in our interviews: 'Our child is fidgety. The father takes a belt into his hands. He says: I am going to raise him the way I was raised. The child goes hysterical' (female, Gorokhovets, 32, mother of three, manual 
worker's wife). Being brought up in the environment where physical abuse is a common tool of demonstrating authority, uninvolved fathers turn to this means of 'communication' with their children since their lack of involvement in every-day interaction leaves them no other means of being a role model or setting a personal example. The only result achieved by such fathering methods is the child 'going hysterical'.

The second fatherhood model which can be extracted from the interviews is situational father/good provider. These fathers see their main goal in financial provision of their children, they are not deeply involved in day-to-day care and work a lot (often far away from home), prefer to spend their free time among their friends (in homo-social environment), fishing, watching sports etc. At the same time these fathers give a lot of effort, time and attention to 'masculine' labour: repairing, reconstructing, building tasks in the household:

Five times a year we [the community of social workers] organise events for the whole family. Fathers come very seldom. On the $23^{\text {rd }}$ of February, we have the following: If it is OK, we are going to come with the mothers. Usually our fathers do not have time, they make excuses that they need to fix something at home. Really, I don't know what makes them so busy (female, Totma, 30, social worker, mother of one, manual worker's wife).

Spending time with the family in mainly female environment makes men feel awkward; they do not consider this parenting practice to be sufficiently 'manly'. For 'good providers' fatherhood is more compatible with doing some odd jobs around the house than by spending time together at a social event where there are likely to be few other fathers.

As Loren Christiansen and Rob Palkovitz (2001) argue, financial provision should not be viewed as oppositional to father's involvement, rather, it should be seen as one component of a father's involvement that is essential but needs appropriate balance. Furthermore, they further suggest that correlational data demonstrate relationships between fathers' economic underperformance and negative components of family development and functioning. A father's ability to provide may also have intergenerational effects on children through observational learning, educational opportunities, and other aspects of developing human capital (in terms of Bourdieu) and skills:

If the mother [interviewee's wife] has asked me to do something, the elder also takes a head saw, a screw gun, and I don't scold him, though he is interfering, because only by eagerness you can develop love for labour, by nothing else... You should not force them, you should show an example (male, Totma, 30, father of two, security guard).

Research shows that the investment of fathers in economic provision has been correlated with enhanced father-child relationships, educational achievement and behavioural adjustment, and children's self-esteem (Marks, Palkovitz 2004). Nevertheless, many families with 'the situational father' cannot keep the 
balance between the financial provision and everyday availability of fathers. In modern conditions families from the potential middle class and manual workers groups are bound not only to provide for their children's basic needs, but also deliver access to entertainment and constantly developing digital technologies, as the rules of the consumerist society demand from them. In small Russian towns, this is solved through numerous bank loans:

Husband: We use payments by instalments, everybody knows us, we can be trusted. All our children have both phones and tablets. Did you buy for them five tablets at once this year?

Wife: Well, they needed them, they asked for them... I want my children to have... So that nobody will say that we have many children but are worse than others. So we have to buy them clothes, footwear and food (interview with a couple, Gorokhovets, 40 and 38, family of nine children, policeman and housewife).

The typical situation of conflict between family and work interests, which many of the families from these social groups face, influences the educational strategies they choose for their children. The parents pragmatically estimate their children's opportunities for social mobility not very highly, so they motivate them to succeed in sports. In terms of Lareau (2016), this strategy can be viewed as a variant of 'natural growth'. Here is one example:

At school, he [his son] is not very good, he is good at sports. It's better for him to grow in a village, as a country-bumpkin, simple, as you say, he will find his way in life anyway, the way he needs... When he comes back from the army, he will be a completely different thing (male, Gorokhovets, 40, father of nine, policeman).

The third group of the fathers are involved parents. According to Joseph Pleck's concept (2010), the father's involvement in childcare has three components, the first being positive engagement in development-promoting activities with the child:

The more there is of this communication, the more you know. Plus you have to ask. And you have to answer to your child. Now is time when my children need me. They are used to me being always at home (male, Totma, 34, father of three, driving instructor).

Physical engagement in childcare is combined with emotional closeness, warmth and responsiveness: 'She [her daughter] is already four, but he [her husband] still takes her to bed in his arms' (female, Totma, 30, mother of one, manual worker's wife). Finally, the third aspect of father's involvement is control, which is a multifaceted concept that includes monitoring, limit-setting, anticipating the child's needs, and participation in making important decisions about the children: 'I want them [his daughters] to get an education and a profession. So they won't depend on anyone' (male, Totma, 38, father of two, manual loader). 
However, at the same time, the fathers from the potential middle class and manual workers groups demonstrate rigid views on women's right to career self-fulfilment: 'I hold somewhat conservative views. It is a woman who is responsible for cosiness and childcare' (male, Totma, 34, father of three, driving instructor). Thus, even male respondents from the 'involved group' show little eagerness to challenge the traditional gender contract.

\section{Conclusion}

This research has focused on gender contracts in contemporary Russian families who live in distant regions. I have considered fatherhood practices from economic and gender perspectives by combining them: to put it simply, money is important, and money influences gender relations. As Marks and Palkovitz (2004) argued, many researchers take financial provision of families for granted and load it with negative meanings, yet, new fathers have good salaries as they tend to be well-educated and come from upper-middle classes. Besides, they are married to well-educated women who also provide substantial financial contributions to the family. In my research, I looked at the situation in other classes: less-educated, low- to middle-class fathers and mothers who do not have these opportunities and must work longer hours or/and multiple jobs, take loans and find other ways to provide for their families.

In the environment of a small Russian town, people face many constraints, including those associated with labour market: there are very few employment possibilities for women with children and, according to the interviews with the mothers, the lack of kindergartens is an immense problem. So, gender contracts in the families of potential middle class and manual workers in Russian province are based on a naturalized division of labour that is the result of existing social and political conditions. As a consequence, very few families negotiate the level of each partner's participation in domestic labour and childcare. Men consider the gender division of labour to be 'natural', women think of it as something they have to deal with in any case. The absence of mutual decision-making process predominantly leads to mothers' exhaustion and fathers' withdrawal from parenthood. To be exact, there are three models of fatherhood discovered in this research: the absent father, the situational father, and the involved father. Importantly, these parental practices and family contracts in small towns in Russia are perceived as unfair at least by one of the partners, something with a potentially detrimental effect on family sustainability and effectiveness in child raising.

\section{References}

Adonyeva S., Olson L. J. (2016) Miry russkoj derevenskoj zhenshhiny. Tradicija, transgressija, kompromiss [The Worlds of Russian Village Women. Tradition, Transgression, Compromise], Moscow: NLO. 
Anikin V., Tikhonova N. (2016) Professional'nyj portret srednego klassa i osobennosti ego jevoljucii [Professional Portrait of the Middle class and thePeculiarities of its Evolution]. M. Gorshkov, N. Tikhonova (eds.) Srednij klass v sovremennoj Rossii. Opyt mnogoletnih issledovanij [The Middle Class in Contemporary Russia. The Experience of Many Years of Studies], Moscow: Ves' Mir: 58-79.

Ashwin S., Lytkina T. (2004) Men in Crisis in Russia: The Role of Domestic Marginalization. Gender \& Society, (18): 189-206.

Bianchi S., Milkie M., Sayer L., Robinson J. (2000) Is Anyone Doing the Housework? Trends in the Gender Division of Household Labor. Social Forces, (79): 191-228.

Blau F. D. (1998) Trends in the Well-Being of American Women, 1970-1995. Journal of Economic Literature, (36): 112-165.

Bott E. (1955) Urban Families: Conjugal Roles and Social Networks. Human Relations, 7 (3): 345-384.

Bourdieu P. (2001) Prakticheskij smysl [Practical Reason], St. Petersburg: Aleteya.

Christiansen S. L., Palkovitz R. (2001) Why the 'Good Provider' Role Still Matters: Providing as a Form of Paternal Involvement. Journal of Family Issues, (28): 84-106.

Coltrane S. (2000) Research on Household Labor: Modeling and Measuring the Social Embeddedness of Routine Family Work. Journal of Marriage and the Family, (62): 1208-1233.

Deutsch F. M. (2010) Strategies Men Use to Resist. M. S. Kimmel, M. A. Messner (eds.) Men's Lives. $8^{\text {th }}$ edition, Boston: Pearson: 413-419.

Erikson R., Goldthorpe J.H. (1992) The Constant Flux: A Study of Class Mobility in Industrial Societies, New York: Oxford University Press.

Federal law (1995) O gosudarstvennyh posobijah grazhdanam, imejushim detej [About State Allowances for Citizens Having Children] N 81-FZ from 19.05.1995.

Federal law (2015) O predel'noj velichine bazy dlja nachislenija strahovyh vznosov v Fond social'nogo strahovanija Rossijskoj Federacii i Pensionnyj fond Rossijskoj Federacii s 1 janvarja $2016 \mathrm{~g}$. [On the Limit Size of Base for Accruing Insurance Payments to the Social Insurance Fund of Russian Federation and Pension Fund of Russian Federation since 1 of January 2016] N 1265 from 26.11.2015.

Hays S. (1996) The Cultural Contradictions of Motherhood, London: Yale University.

Hochschild A., Machung A. (2012) The Second Shift: Working Families and the Revolution at Home, New York: Pinguin Books.

Karavay A. (2016) Otnoshenie rossijskih rabochih k svoim resursam: finansam, zdorov'ju i svobodnomu vremeni [The Attitude of Russian Workers to Managing Their Resources: Finances, Health and Spare Time]. Zhurnal issledovanij social'noj politiki [The Journal of Social Policy Studies], 14 (2): 229-244.

Lareau A. (2011) Unequal Childhood. Class, Race, and Family life. $2^{\text {nd }}$ ed., Berkley: University of California Press.

Marks L., Palkovitz R. (2004) American Fatherhood Types: The Good, the Bad, and the Uninterested. Fathering: A Journal of Theory, Research, and Practice about Men as Fathers, 2 (2): 113-129. 
Mason J. (2002) Qualitative Researching, London: Sage.

Pleck J.H. (2010) Fatherhood and Masculinity. J.H. Pleck (ed.) The Role of the Father in Child Development. 5th ed., Hoboken: John Wiley \& Sons: 67-107.

Risman B. J. (2004) Gender as a social structure: theory wrestling with activism. Gender \& Society, 18 (4): 429-450.

Rodríguez-Ménes J., Puig D., Sobrino C. (2014) Poly- and Distinct- Victimization in Histories of Violence against Women. Journal of Family Violence, (29): 849-858.

Sayer L.C. (2005) Gender, Time and Inequality: Trends in Women's and Men's Paid Work, Unpaid Work and Free Time. Social Forces, 84 (1):285-303.

Sayer L.C., Cohen P.N., Casper L. M. (2004) Women, Men and Work. The American People Census 2000, New York: Russell Sage Foundation and Population Reference Bureau.

Shadrina A. (2017) Dorogie deti: sokrashhenie rozhdaemosti i rost 'ceny' materinstva $v$ XXI veke [Expensive Children: The Decrease in Fertility and the Growth of the Motherhood 'Price' in Twenty-First Century], Moscow: NLO.

Utrata J. (2008) Keeping the Bar Low: Why Russia's Nonresident Fathers Accept Narrow Fatherhood Ideals. Journal of Marriage and Family, 70 (5): 1297-1310.

Utrata J. (2015) Women Without Men. Single Mothers and the Family Change in the New Russia, Ithaca, NY: Cornell University Press. 